\title{
A Bibliometric Analysis and Visualisation of Research Trends in Allergy of hip-implants
}

\author{
Raman Kumar \\ Department of Mechanical Engineering, Chandigarh University, \\ Gharuan,Punjab,India. 140413
}

Article History: Received: 11 January 2021; Accepted: 27 February 2021; Published online: 5 April 2021

\begin{abstract}
A diversified set of metals are used for hip-implants. The bibliometric analysis had been conducted to understand the active authors, organizations, journals, and countries involved in the research domain of "Allergy of hip-implants". All published articles related to "Allergy of hip-implants" from "Scopus", were analyzed using the VOS viewer to develop analysis tables and visualization maps. This article had set the objective to consolidate the scientific literature regarding "Allergy of hipimplants" and also to find out the trends related to the same. The most active journals in this research domain were the Acta Orthopaedica and Journal of Orthopaedic Surgery and Research. The most active countries were the United States of America and the United Kingdom. The leading organization engaged in the research regarding allergy of hip-implants was the Hospital of Special Surgery, United States of America. The most active author who had made valuable contributions related to the allergy of hip implants was Thomas P.
\end{abstract}

Keywords: Allergy, hip-implants, Material engineering, Bibliometric analysis, VOS viewer,

\section{Introduction}

An engineered medical device to replace a missing or damaged biological structure is known as an implant. Different types of metals and materials are used to create implants. The allergy to metal implants is a serious issue to be addressed. Metal releases from implants cause various types of allergies and hypersensitivity [1] [2]. The safety of the material used is an important determinant while choosing implants[3]. Material engineering and surface engineering can play a significant role in improving safety and reducing allergies associated with metal implants[4].

Allergy of Nickel implants had been reported regarding hip implants [5] Allergy of Nickel-based total hip arthroplasty [6]. Hypersensitivity to Nickel can be in cases of orthopedic implants or delayed hypersensitivity among patients who underwent a hip replacement. Such patients may with pain, fatigue, and contact allergic dermatitis, and instability [7]. Chances for postoperative hypernickelemia and nickeluresis should be counted in cases of the nickel-based porous-coated knee or hip prostheses [8]. The issue of hypersensitivity had been reported in hip implants based on cobalt-chromium alloys [9];[10]. Similarly, allergic skin disease is another issue associated with patients who underwent hip replacement with metal-on-metal (MOM) bearings. This happens due to corrosion and the release of wear debris and high levels of metal ions in the blood [11].

Stainless steel is often considered a safe metal for hip implants in comparison with Nickel [12]. The Zirconium implants are known for high resistance to fracture and flexural strength, lower levels of allergies, and excellent biocompatibility [13]. Titanium is one of the widely used metals for hip implants. The release of Titanium particles from the bio-implants may lead to bone losses in addition to Titanium allergy [14][15].

This bibliometric analysis will be a useful platform for future researchers by realizing the top researchers, organizations, and countries involved in research regarding allergies of hip-implants[16]. This article is arranged into four sections. The first section is the introduction, followed by the discussion of the methodology by which the research was conducted. The third section deals with results and discussion. The fourth section deals with the conclusion. The following research objectives and research questions were framed for conducting bibliometric analysis systematically.

\subsection{Research Objectives}

a) To consolidate the literature regarding allergy of hip-implants

b) To find out the trends related to research in allergy of hip-implants

\subsection{Research Questions}

a) Who are the active researchers working on the allergy of hip implants?

b) Which are the main organizations and countries working on the allergy of hip-implants?

c) Which are the main journals related to an allergy to hip-implants?

\section{Research Methodology}

Scopus files had been used for this article. For the article selection, the Boolean used was TITLE-ABS (Allergy hip-implants) on 08/03/2021. All the tables in this paper were created by using Microsoft Excel and VOS Viewer. Grammarly was used for spelling and grammar checks. Mendeley was used for article review and 
citation. This paper had been inspired by bibliometric analysis in its presentation style, analysis, and methodology from the works [17]-[23].

\section{Results and discussion}

\subsection{Results}

This first round of search produced an outcome of 66 documents, in six languages, out of which 45 documents were in English. The classification of document categories is shown in Figure 1. For improving the quality of the analysis, we had selected only the peer-reviewed articles and all other documents had not been considered. Thus after using filters "Article" and "English" the second round search produced an outcome of 25 English articles (both open access and others) and had been used to conduct bibliometric analysis and visualization using VOS Viewer. The English research articles in this domain since 1988 had been shown in Figure 2.

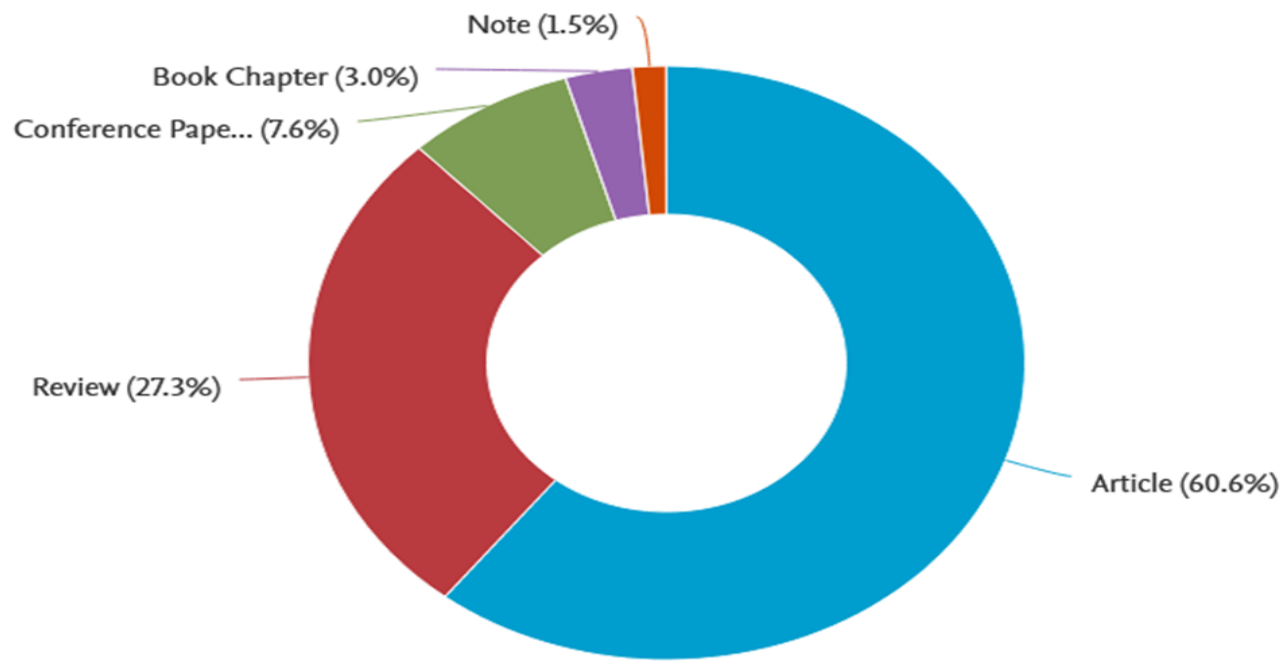

Figure 1: Classification of the documents on "Allergy of hip-implants", Source: www.scopus.com

4

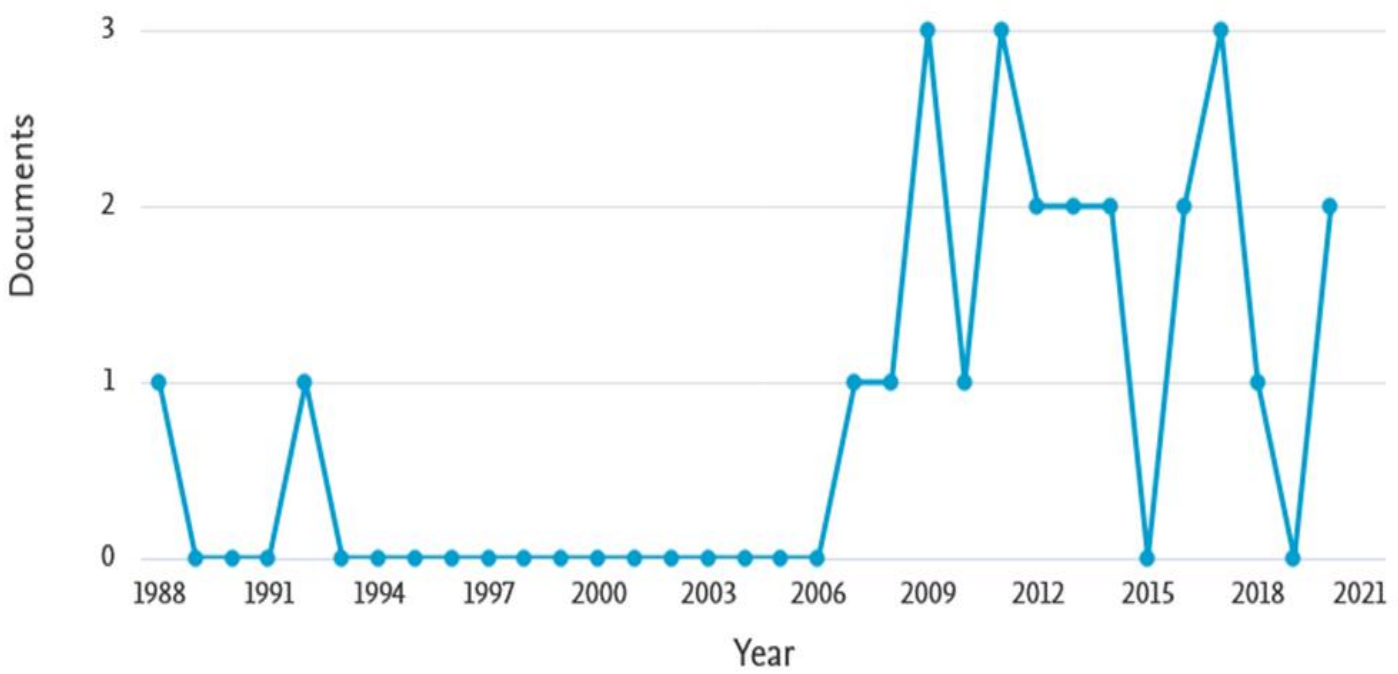

Figure 2: Period wise publication of articles, Source: WWW.scopus.com

Co-authorship analysis of top authors had been shown in figure 3. For a better presentation of the analysis, the parameters used were the minimum number of documents of an author as one and the minimum number of citations of authors as 34. This combination plotted the map of 28 authors, in six clusters. The overlay visualization map of co-authorship analysis plotted in Figure 3, points out the major researchers with their strong co-authorship linkages and clusters involved. 


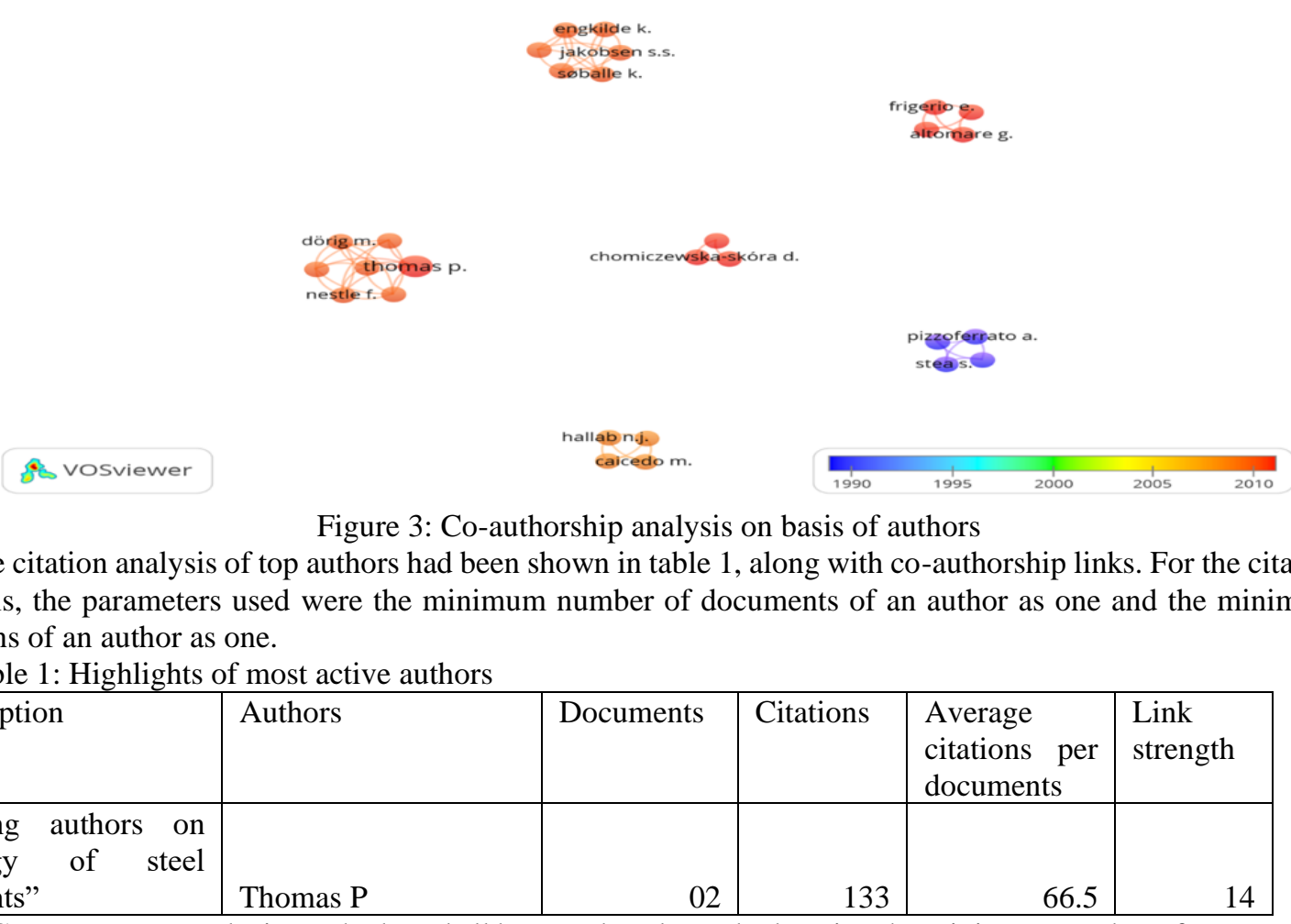

In Co-occurrence analysis, we had used all keyword analyses, by keeping the minimum number of occurrences of a keyword as 5. This combination plotted the map of 30 thresholds, in three clusters. The overlay visualization of co-occurrence analysis of keywords has been shown in Figure 4.

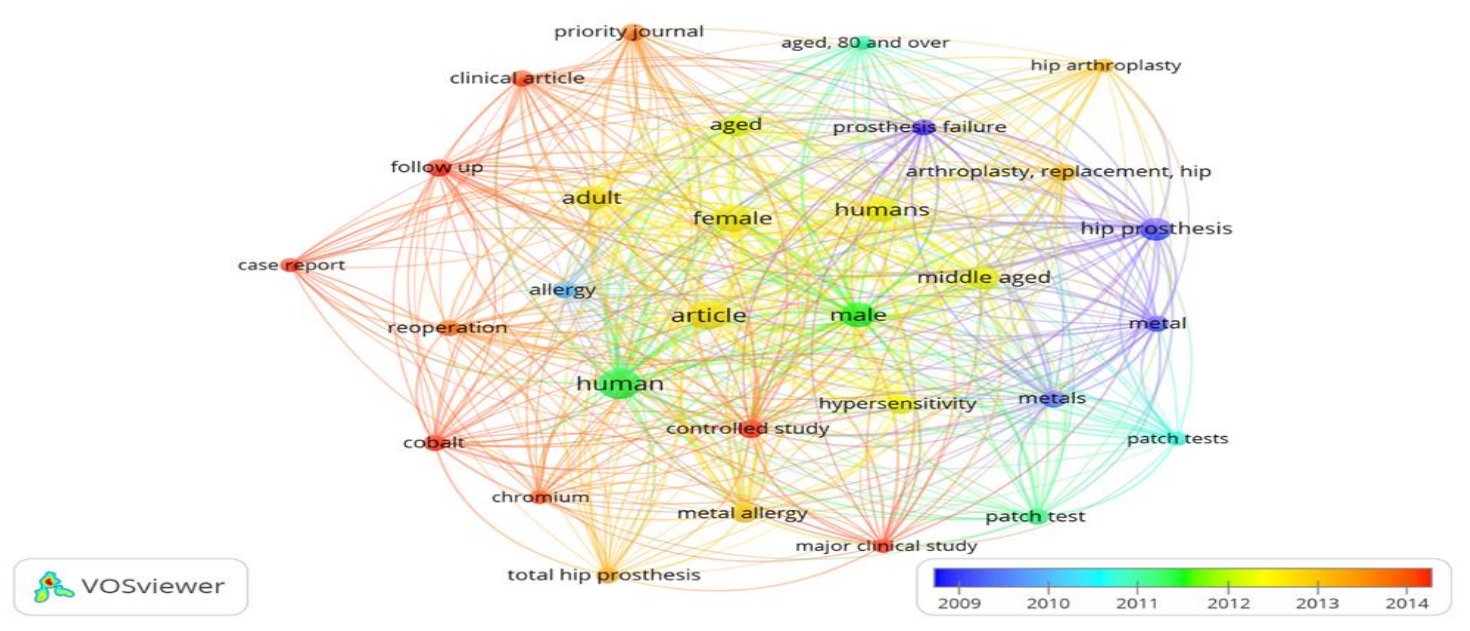

Figure 4: Co-occurrence analysis on basis of all keywords

The leading organizations engaged in research on "Allergy on hip-implants" had been found out by the volume of publications and citation analysis, the parameters used are the minimum number of documents of an organization as one and the minimum number of citations of organizations as one. The leading organization in the research regarding "Allergy on hip-implants", with the highest number of publications and citations, was the Hospital of Special Surgery, United States of America (Refer to table 2).

Table 2: Highlights of the most active organization

\begin{tabular}{|l|l|l|l|l|}
\hline Organizations & Country & Documents & Citations & $\begin{array}{l}\text { Average } \\
\text { Citations per } \\
\text { document }\end{array}$ \\
\hline Hospital of Special Surgery & $\begin{array}{l}\text { United States of } \\
\text { America }\end{array}$ & 3 & 33 & 11 \\
\hline
\end{tabular}

Co-authorship analysis of the countries engaged in the research on "Allergy of hip-implants" had been shown in Figure 5. The overlay visualization map of co-authorship analysis plotted in Figure 5, points out the main countries with their strong co-authorship linkages and clusters involved. 


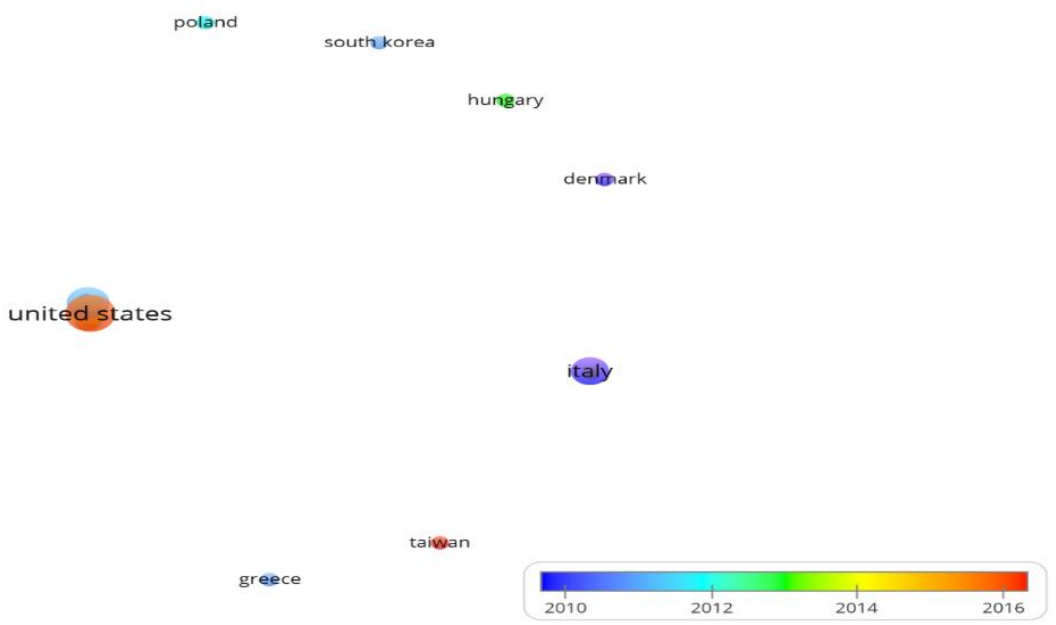

Figure 5: Co-authorship analysis on basis of countries

The citation analysis of top countries had been shown in table 3, along with co-authorship links. For the citation analysis, the parameters used were the minimum number of documents of a country as one and the minimum citations of the country as one.

Table 3: Highlights of Active Countries

\begin{tabular}{|c|c|c|c|c|}
\hline Description & Country Document & Citation & Link strength \\
\hline $\begin{array}{c}\text { The country with the } \\
\text { highest publication }\end{array}$ & $\begin{array}{c}\text { United States of } \\
\text { America }\end{array}$ & 7 & 153 & 1 \\
\hline $\begin{array}{c}\text { The country with the } \\
\text { highest citations, and co- } \\
\text { authorship links }\end{array}$ & United Kingdom & 4 & 157 & 7 \\
\hline
\end{tabular}

The most active country in this research domain was the United States of America, with the highest number of publications, and the United Kingdom with the highest, citations, and co-authorship links.

Link analysis and citation analysis were used to identify the most active journal in this research domain. We have taken the parameters of the minimum number of documents of a journal as one and the minimum number of citations of a journal as one for the link analysis and citation analysis. Highlights of the most active and relevant journals related to "Allergy of hip-implants" are shown in table 4 . Table 4 shows the journal activity of this research domain through parameters of publication volume, citations, and co-authorship linkages.

Table 4: Analysis of journal activity

\begin{tabular}{|l|c|c|c|c|}
\hline Description & Journal details & Documents & Citations & $\begin{array}{l}\text { Average } \\
\text { citations } \\
\text { per } \\
\text { documents }\end{array}$ \\
\hline $\begin{array}{c}\text { Leading Journals on } \\
\text { the allergy of hip- } \\
\text { implants }\end{array}$ & $\begin{array}{c}\text { Acta } \\
\text { Orthopaedica }\end{array}$ & 2 & 79 & 7 \\
\cline { 2 - 5 } & $\begin{array}{c}\text { Journal of } \\
\text { Orthopaedic Surgery } \\
\text { and Research }\end{array}$ & 2 & 123 & 4 \\
\hline
\end{tabular}

From the above discussion regarding the bibliometric patterns in the research regarding the allergy of hipimplants, this research had observed a gradual increase in research interest regarding allergy of hip-implants from the starting of the millennium and the momentum is going on positively. This points out the relevance and potential of this research domain (Refer to Figure 2). The most active author in this research domain was Thomas P. with the highest publication, citations, and co-authorship links (Refer to table 1). The overlay analysis of top countries researching allergy of hip-implants indicates that the United States of America and United Kingdom were the leading countries relating to the highest number of publications; and citations and co-authorship links respectively (Refer to figure 5). The top journals of this research domain were identified as the Acta Orthopaedica and Journal of Orthopaedic Surgery and Research. From these wide sources of information, researchers can focus on top journals where they can identify the most relevant and highly cited articles regarding allergy hip-implants.

\section{Conclusion}

Allergy of hip-implant was an interesting research domain and the most active journal related to this research domain was the Acta Orthopaedica and Journal of Orthopaedic Surgery and Research. The most active countries were the United States of America and the United Kingdom. The leading organization engaged in the research regarding allergy of hip-implants was the Hospital of Special Surgery, United States of America. The most active 
author who had made valuable contributions related to the allergy of hip implants was Thomas P. This research domain offers a new avenue for researchers and future research can be on innovations in allergy of hip-implants.

\section{References}

1. Fisher, "The safety of stainless steel hip prosthesis in nickel-sensitive individuals," Cutis, vol. 52, no. 4, p. 193, 1993.

2. Kolkailah et al., "Bibliometric Analysis of the Top 100 Most Cited Articles in the First 50 Years of Heart Transplantation,” Am. J. Cardiol., vol. 123, no. 1, pp. 175-186, 2019.

3. X. Tran et al., "The current research landscape of the application of artificial intelligence in managing cerebrovascular and heart diseases: A bibliometric and content analysis," Int. J. Environ. Res. Public Health, vol. 16, no. 15, 2019.

4. L. Crawford and P. M. Hardwicke, "Experimental leprosy: A model of epithelioid cell granuloma," Int. J. Dermatol., vol. 50, no. 3, pp. 255-261, 2011.

5. Delimar, I. Bohaček, Z. Paštar, and J. Lipozenčić, "Orthopedic and cutaneous reactions to nickel after total hip replacement," Acta Dermatovenerologica Croat., vol. 26, no. 1, pp. 39-43, 2018.

6. Kaur, G. S. Aujla, N. Kumar, A. Y. Zomaya, C. Perera, and R. Ranjan, "Tensor-Based Big Data Management Scheme or Dimensionality Reduction Problem in Smart Grid Systems: SDN Perspective," IEEE Trans. Knowl. Data Eng., vol. 30, no. 10, pp. 1985-1998, Oct. 2018.

7. Singh et al., "Investigations of Machining Characteristics in the Upgraded MQL-Assisted Turning of Pure Titanium Alloys Using Evolutionary Algorithms," Materials (Basel)., vol. 12, no. 6, Mar. 2019.

8. Shahid et al., "Characteristics of highly cited articles in heart failure: A bibliometric analysis," Future Cardiol., vol. 16, no. 3, pp. 189-197, 2020.

9. I.-M. Borrmann, "Zirconium dioxide implants in dental implantology [Zirkondioxyimplantate in der dentalen implantologie]," Asthetische Zahnmedizin, vol. 12, no. 1, pp. 54-56, 2009.

10. J. Liao et al., "The most cited articles in coronary heart disease: A bibliometric analysis between 1970 and 2015," Int. J. Cardiol., vol. 222, pp. 1049-1052, 2016.

11. J. Sunderman F.W. et al., "Cobalt, chromium, and nickel concentrations in body fluids of patients with porous-coated knee or hip prostheses,” J. Orthop. Res., vol. 7, no. 3, pp. 307-315, 1989.

12. L. Rodríguez-Padial et al., "Trends and Bibliometric Impact of Research Grants of the Spanish Society of Cardiology/Spanish Heart Foundation (2007-2012) [Evolución e impacto bibliométrico de las becas de la Sociedad Española de Cardiología/Fundación Española del Corazón en el periodo 2007-2012]," Rev. Esp. Cardiol., vol. 72, no. 12, pp. 1012-1019, 2019.

13. M. Thomsen, M. Rozak, and P. Thomas, "Use of allergy implants in Germany: Results of a survey [Verwendung von Allergieimplantaten in Deutschland: Ergebnisse einer Umfrage]," Orthopade, vol. 42, no. 8, pp. 597-601, 2013.

14. M. Z. B. Abdullah, M. A. Ahmad, A. N. Abdullah, M. H. Othman, P. Hussain, and A. Zainuddin, "Metal Release of Multilayer Coatings by Physical Vapour Deposition (PVD)," in Procedia Engineering, 2016, vol. 148, pp. 254-260.

15. N. Aggarwal, K. Kaur, A. Vasishth, and N. K. Verma, "Structural, optical and magnetic properties of Gadolinium-doped ZnO nanoparticles,” J. Mater. Sci. Mater. Electron., vol. 27, no. 12, pp. 13006-13011, 2016.

16. N. Bizzotto et al., "Chromium-induced diffuse dermatitis with lymph node involvement resulting from Langerhans cell histiocytosis after metal-on-metal hip resurfacing,” Br. J. Dermatol., vol. 172, no. 6, pp. 1633-1636, 2015.

17. O. M. Posada, R. J. Tate, and M. H. Grant, "Toxicity of cobalt-chromium nanoparticles released from a resurfacing hip implant and cobalt ions on primary human lymphocytes in vitro," J. Appl. Toxicol., vol. 35, no. 6, pp. 614-622, 2015.

18. O. M. Posada, R. J. Tate, R. M. Dominic Meek, and M. Helen Grant, "In Vitro analyses of the toxicity, immunological, and gene expression effects of cobalt-chromium alloy wear debris and co ions derived from metal-on-metal hip implants," Lubricants, vol. 3, no. 3, pp. 539-568, 2015.

19. P. Thomas et al., "Increased metal allergy in patients with failed metal-on-metal hip arthroplasty and periimplant T-lymphocytic inflammation,” Allergy Eur. J. Allergy Clin. Immunol., vol. 64, no. 8, pp. 1157$1165,2009$.

20. R. Comino-Garayoa, J. Cortés-Bretón Brinkmann, J. Peláez, C. López-Suárez, J. M. Martínez-González, and M. J. Suárez, "Allergies to Titanium Dental Implants: What Do We Really Know about Them? A Scoping Review.," Biology (Basel)., vol. 9, no. 11, Nov. 2020.

21. S. Ullah, S. U. Jan, H. U. Rehman, N. I. Butt, M. A. Rauf, and S. Shah, "Publication trends of Pakistan Heart Journal: A bibliometric study,” Libr. Philos. Pract., vol. 2019, 2019.

22. T. Albrektsson, B. Chrcanovic, J. Mölne, and A. Wennerberg, "Foreign body reactions, marginal bone loss and allergies in relation to titanium implants.,” Eur. J. Oral Implantol., vol. 11 Suppl 1, pp. S37S46, 2018.

23. T. Farhat et al., "Research in congenital heart disease: A comparative bibliometric analysis between developing and developed countries," Pediatr. Cardiol., vol. 34, no. 2, pp. 375-382, 2013 